\title{
GAMBARAN ADEKUASI (UREUM \& KREATININ), HAEMOGLOBIN, ALBUMIN, SERTA KUALITAS HIDUP PADA PASIEN GAGAL GINJAL KRONIK YANG MENJALANI HEMODIALISA
}

\author{
Moh. Fuad Almubarok ${ }^{1)}$, Dwi Setiowati ${ }^{2)}$ \\ ${ }^{1}$ Dosen Keperawatan Politeknik Karya Husada Jakarta \\ Email: el_mubaraq@yahoo.co.id \\ ${ }^{2}$ Dosen Keperawatan UIN Syarif Hidayatullah Jakarta \\ Email: dwisetiowati83@gmail.com
}

\begin{abstract}
Haemodialysis may impact on various aspects of patients, including: their daily activities, social roles and psychological aspects. The application of re-use and single-use methods of haemodialysis could be resulting in different quality of life of haemodialysis patients. This study aimed to descript Adequacy, levels of Ureum \& Creatinin, Haemoglobin, Albumin and explore quality of life of kidney failure patients undergoing haemodialysis with single-use and re-use methods. This descriptive study used cross sectional approach, recruited 70 kidney failure patients undergoing haemodialysis by consecutive sampling technique. Data collecting used KDQOL-SF 36 questionnaires and medical record, analysis used univariat and bivariate: T-test and chi-square test to determine the relating factors of quality of life. The result revealed that there were 45,7\% respondents with single-use method had good quality of life and 34,30\% respondents with re-use method had good quality of life. The result revealed that there were 45,70\% respondents with single-use method had Adequated dialysis and $40 \%$ respondents with re-use method had Adequated dialysis. Respondents with single-use method had median of Albumin Level 3,20 gr/dl and 3,16 rg/dl respondents with re-use method had mean of level Albumin. Respondents with single-use method had mean of Haemoglobin Level 9,38 gr/dl and 9,69 gr/dl respondents with re-use method.
\end{abstract}

Keywords: Kidney Failure Patients, Single-use and Re-use Haemodialysis Methods, Adequacy, Haemoglobin, Albumin, Quality of Life

\section{PENDAHULUAN}

Gagal ginjal adalah suatu kondisi terjadinya gangguan pada sistem renal yang bersifat progresif dan irreversibel sehingga menyebabkan kegagalan dalam mempertahankan metabolisme elektrolit dan metabolisme lainnya dalam darah serta sindroma uremia (Wein, Kavoussi, Novick, Partin \& Peters, 2010). Gagal ginjal atau ESRD (End State Renal Disease) didefinisikan juga sebagai penurunan laju filtrasi glomerulus kurang dari $15 \mathrm{ml} /$ menit dengan manifestasi berupa sesak nafas yang berat, ketidakmampuan mengatur cairan dan elektrolit, pengaturan tekanan darah, biogenesis eritropoitin, sinproposal penelitian 1,25-dihidroksikalsiferol dan kegagalan sinproposal penelitian prostaglandin sehingga membutuhkan penanganan dialisis (Black \& Hawks, 2010). Penderita gagal ginjal di United States menurut USRDS (United States Renal Data System) pada tahun 2013 sebesar 549.448 kasus/satu juta penduduk, meningkat pada satu tahun berikutnya 560.751 kasus/satu juta penduduk dan estimasi kenaikan angka penderitanya pada tahun 2017 adalah sebesar $0,002 \%$. Insidensi gagal ginjal di negara maju lainnya yaitu Inggris, pada 
tahun 2013 sebesar 149 kasus/satu juta penduduk. Gagal ginjal di negara berkembang seperti Thailand, pada tahun 2013 adalah sebesar 50.110 kasus/satu juta penduduk dan meningkat pada satu tahun berikutnya menjadi 51.456 kasus/satu juta penduduk. Di Indonesia jumlah gagal ginjal menurut survei yang dilakukan oleh PERNEFRI (Perhimpunan Nefrologi Indonesia) pada tahun 2011 sebesar 13.619 penderita, tahun 2013 jumlah penderita sebesar 13.719 dan jumlah ini diperkirakan akan meningkat pada tahun 2014 menjadi 14.134. Populasi gagal ginjal di Indonesia cukup tinggi sehingga perlu mendapatkan perhatian yang serius pada manifestasi yang muncul.

Manifestasi dari gagal ginjal yang sering muncul adalah gangguan keseimbangan cairan dan elektolit (terjadi edema), anuria (produksi urin Hemodialisis (HD) adalah manajemen terapeutik bagi pasien gagal ginjal yang berfungsi menggantikan fungsi ginjal untuk mengeluarkan sisa hasil metabolisme. HD ini bertujuan untuk mencegah kematian dan memperpanjang usia harapan hidup serta mengendalikan gejala uremia, namun tidak menyembuhkan dan mengembalikan fungsi ginjal pada kondisi normal (Nicola, 2011)

Hemodialisis (HD) dalam praktiknya sangatlah penting untuk mencegah sindroma uremia, menurunkan potensi komplikasi, sehingga akan memperpanjang usia harapan hidup bagi para penderita gagal ginjal kronik. Metode HD yang diterapkan saat ini ada dua yaitu single-use dan reuse. Masing-masing metode ini memiliki keungggulan dan kekurangan masing-masing. Pada single-use tentunya tidak akan ada kerusakan membrane dialiser yang disebabkan oleh tindakan sterilisasi, oleh karenanya potensi kerusakan selaput lendir sistem respirasi, integumentum dan mata dapat dihindarkan. Terlepas dari hal itu, para nefrolog internasional menyebutkan jika metode reuse diberikan dengan tepat maka potensi tersebut juga bisa dicegah, dimana proses sterilisasinya dilakukan dengan benar dan tepat. Saat ini telah berkembang pesat teknik dan alat-alat sterilisasi dialiser yang memiliki kemampuan sterilisasi baik dan menghindarkan membrane dari kerusakan, salah satunya adalah teknik sterilisasi otomatis (Black \& Hawks, 2010).

Sterilisasi dengan teknik otomatis ini mampu memberikan hasil setara dengan single-use sampai dengan 40 kali penggunaan. Beberapa hasil penelitian sebelumnya menyebutkan jika metode single-use dan reuse secara klinis tidak ada perbedaan hasil kemampuan mengeluarkan ureum, adekuasi dan prognosis kondisi penderita gagal ginjal. Hasil yang berbeda ditunjukkan pada aspek psikologis yaitu adanya perbedaan tingkat depresi dan stress, juga ditemukan perbedaan pada aspek yang lain yaitu kemampuan menjalankan aktivitas sehari-hari, bersosial, serta kondisi kesehatan secara umum. Oleh karenanya penilaian terhadap dampak aspek tersebut sangat penting sebab akan berkaitan langsung dengan kualitas hidup. Selain hal itu penting untuk mengevaluasi nilai $\mathrm{HB}$, Ureum, Kreatinin, dan Albumin pada masing-masing responden yang dilakukan HD dengan metode single-use dan reuse, untuk dapat lebih melihat perbedaan pada level laboratoris sebagai upaya dalam mengevaluasi pelaksanaan metode tersebut (Carod \& Artal, 2012).

Kualitas hidup yang baik akan berdampak terhadap kemampuan seseorang menjalani kehidupannya dengan kompleksitas yang mereka miliki mulai dari aspek biologis, psikologis, spiritual dan kultural (WHOQOL Group, 2010). Para ahli nefrologi menyebutkan bahwa untuk menentukan keberhasilan HD ada hal yang perlu dievaluasi, diantaranya adalah adekuasi dialisis dan kualitas hidup pasien setelah dilakukan HD, sehingga dapat membantu dalam menentukan intervensi keperawatan untuk meningkatkan kualitas hidup tersebut (Malekmanen et al. 2014; Wein \& Kavoussi, 2012).

Penelitian sebelumnya pernah dilakukan oleh Yokohama (2012), penelitian tersebut melihat pengaruh penggunaan kompabilitas dan permeabilitas dialiser single-use terhadap anemia, eritropoeitin, dan pengaruhnya terhadap mortalitas pada pasien gagal ginjal di Jepang. Hasilnya, ditemukan pengaruh yang spesifik penggunaan dilaser single-use 
pada pemeriksaan anemia, eritropoetin dan mortalitas. Penelitian Marshall, Walker, Polkinghorne \& Lynn (2014) meneliti pengaruh antara pemakaian dialiser reuse yang dikombinasikan dengan dialiser singleuse terhadap hospitalisasi dan mortalitas pada pasien gagal ginjal di Inggris. Hasil penelitian menyebutkan bahwa ada pengaruh yang signifikan pada penurunan hospitalisasi, namun tidak pada angka mortalitas pasien gagal ginjal. Pada penelitian lainnya disebutkan bahwa dialiser single-use memiliki nilai yang lebih baik dalam menurunkan depresi pada pasien gagal ginjal jika dibandingkan dengan dialiser reuse (Maksum, 2017)

\section{METODE PENELITIAN}

Desain penelitian ini adalah deskriptif dengan pendekatan cross sectional, dengan total sampel 70 responden HD single-use dan reuse (masing-masing berjumlah 35 responden). Variabel yang diukur pada penelitian ini adalah kualitas pada kelompok single-use dan re-use dengan menggunakan kuesioner KDQOL SF-36, sebanyak 39 pertanyaan.
Analisis dilakukan secara univariat. Analisis univariat bertujuan untuk melihat karakteristik responden yang meliputi umur, jenis kelamin, pekerjaan, pendidikan, suku, tekanan darah, adekuasi, kadar $\mathrm{Hb}$ dan kadar albumin.organ pada tubuh akan mengalami penurunan, termasuk organ ginjal (Dickson, Buck, \& Riegel, 2013).

\section{HASIL DAN PEMBAHASAN}

1. Karakteristik Responden Single-use dan Re-use.

\section{a. Umur}

Rata-rata umur pada kelompok single-use maupun re-use adalah $>40$ tahun. Pada masa ini produksi hormon testosteron dan androgen pada kaum laki-laki sudah mengalami penurunan. Begitu pula dengan hormon estrogen dan progesteron pada kaum perempuan juga mengalami penurunan hingga $>35 \%$, proses ini terjadi secara progressif hingga akhirnya tidak diproduksi sama sekali. Kaum perempuan mengalami masa yang disebut menopause sedangkan kaum pria mengalami masa andropause. Pada tahap ini semua

Tabel 1. Distribusi Kelompok Responden HD Single-use \& Re-useBerdasarkan Umur di RSPAD Gatot Subroto \& RS PGI Cikini Jakarta, Periode Agustus-November, 2017 (n=70)

\begin{tabular}{clllllll}
\hline Var. & Kel. & Mean & \pm SD & $\begin{array}{l}\text { Min- } \\
\text { Max }\end{array}$ & 95 \% CI & \\
\hline & Single- & 45,03 & \pm & 25 & - & 40,91 & - \\
Umur (Th) & use & & 11,99 & 71 & 49,15 & \\
\cline { 2 - 7 } & \multirow{2}{*}{ Re-use } & 41,00 & $\pm 9,51$ & $25-65$ & 39,67 & - \\
& & & & & 46,21 & \\
\hline
\end{tabular}




\section{b. Jenis Kelamin, Suku, Pendidikan, dan Pekerjaan}

Tabel 2. Distribusi Kelompok Responden HD Single-use \& Re-use Berdasarkan Jenis Kelamin, Suku, dan Pendidikan responden HD di RSPAD Gatot Subroto \& RS PGI Cikini Jakarta, Periode Agustus-November, $2017(\mathrm{n}=70)$

\begin{tabular}{|c|c|c|c|c|}
\hline Var. & Kel. & Kategori & (n) & $(\%)$ \\
\hline \multirow{6}{*}{ Jenis kelamin } & \multirow{3}{*}{ Single-use } & Laki-laki & 27 & 77,10 \\
\hline & & Perempuan & 8 & 22,90 \\
\hline & & Total & 35 & 100,00 \\
\hline & \multirow{3}{*}{ Re-use } & Laki-laki & 22 & 62,90 \\
\hline & & Perempuan & 13 & 37,10 \\
\hline & & Total & 35 & 100,00 \\
\hline \multirow{14}{*}{ Suku } & \multirow{7}{*}{ Single-use } & Jawa & 17 & 48,60 \\
\hline & & Sunda & 3 & 8,60 \\
\hline & & Batak & 1 & 2,90 \\
\hline & & Melayu & 3 & 8,60 \\
\hline & & Betawi & 11 & 31,40 \\
\hline & & Lainnya & 0 & 0,00 \\
\hline & & Total & 35 & 100,00 \\
\hline & \multirow{7}{*}{ Re-use } & Jawa & 10 & 28,60 \\
\hline & & Sunda & 1 & 2,90 \\
\hline & & Batak & 8 & 22,90 \\
\hline & & Melayu & 2 & 5,70 \\
\hline & & Betawi & 7 & 20,00 \\
\hline & & Lainnya & 7 & 20,00 \\
\hline & & Total & 35 & 100,00 \\
\hline \multirow{12}{*}{ Pendidikan } & \multirow{6}{*}{ Single-use } & SD & 1 & 2,90 \\
\hline & & SMP & 1 & 2,90 \\
\hline & & SMA & 25 & 71,40 \\
\hline & & $\mathrm{D} 3 / \mathrm{S} 1$ & 8 & 22,90 \\
\hline & & S2/Magister & 0 & 0,00 \\
\hline & & Total & 35 & 100,00 \\
\hline & \multirow{6}{*}{ Re-use } & SD & 0 & 0,00 \\
\hline & & SMP & 4 & 11,40 \\
\hline & & SMA & 21 & 60,00 \\
\hline & & $\mathrm{D} 3 / \mathrm{S} 1$ & 10 & 28,60 \\
\hline & & S2-S3 & 0 & 0,00 \\
\hline & & Total & 35 & 100,00 \\
\hline
\end{tabular}

\section{(1) Jenis Kelamin}

Responden pada penelitian ini mayoritas berjenis kelamin laki-laki baik pada kelompok single-use maupun re-use, yaitu 27 responden $(77,10 \%)$ pada kelompok single-use dan 22 orang $(62,90 \%)$ pada kelompok re-use. Hal ini dapat dipicu oleh etiologi yang menyebabkan terjadinya gagal ginjal. Pada umumnya gagal ginjal yang terjadi pada responden sebagian besar dipicu oleh penyakit hipertensi yang lebih berpotensi terjadi pada laki-laki (Black \& Hawks, 2010).

\section{(2) Suku}

Responden pada HD single-use terbanyak bersuku jawa yaitu sebesar 17 orang $(48,60 \%)$, sedangkan jumlah paling sedikit adalah suku Batak yaitu 1 orang $(2,90 \%)$. Demikian juga pada Responden HD re-use, jumlah terbanyak adalah suku Jawa yaitu sebanyak 10 orang $(28,60 \%)$, sedangkan jumlah paling sedikit adalah suku 
Melayu 2 orang $(5,70 \%)$ dan suku Sunda 1 orang $(2,90 \%)$. Dari data tersebut diketahui bahwa jumlah terbanyak suku yang menjalani HD pada kedua kelompok adalah suku jawa dan dapat diketahui pula kedua kelompok memiliki suku yang beragam (heterogen).

Pentingnya melihat suku atau budaya pada penelitian ini dikarenakan hal tersebut dapat mengakibatkan perbedaan interpretasi terkait dengan pandangan mengenai hidup sehat, menangani keluhan yang muncul, dan cara mengobati atau mencari pertolongan serta merawat orang sakit. Perbedaan suku juga dapat mempengaruhi seseorang dalam mengambil sebuah keputusan tentang penggunaan layanan kesehatan. Hal ini juga dapat berlaku untuk pasien yang mengalami gagal ginjal, misalnya dalam menentukan jenis dialisis yang akan mereka jalani, memilih akses vaskuler, mendukung anggota keluarga dalam melaksanakan HD, dan memberikan motivasi untuk mematuhi jumlah asupan cairan dan protein yang akan berdampak terhadap kualitas hidup pasien gagal ginjal (Wish, Jay, Weigel \& Kelly, 2014).

\section{(3) Pendidikan}

Pendidikan SMA memiliki jumlah terbanyak pada kedua kelompok responden baik single-use maupun re-use. Status pendidikan berpengaruh terhadap kemampuan memahami dan melaksanakan regiment terapeutik dari penyakit gagal ginjal. Seiring meningkatnya pengetahuan, maka angka kepatuhan menjalani HD juga akan meningkat (Wein \& Kavoussi, 2013 \& Stone, 2012)

\section{c. Tekanan Darah dan Adekuasi}

Tabel 3. Distribusi Kelompok Responden HD Single-use dan Re-use Berdasarkan Tekanan Darah dan Adekuasi, RSPAD Gatot Subroto \& RS PGI Cikini Jakarta Periode Agustus-November, 2017 $(n=70)$

\begin{tabular}{|c|c|c|c|c|}
\hline Var. & Kel. & Kategori & (n) & $(\%)$ \\
\hline \multirow{8}{*}{ Tekanan Darah } & \multirow{3}{*}{ Single-use } & $\begin{array}{l}\text { Normal- } \\
\text { Ringan }\end{array}$ & 23 & 65,70 \\
\hline & & Hipertensi & 13 & 34,30 \\
\hline & & $\begin{array}{l}\text { Hipertensi Berat } \\
\text { Total }\end{array}$ & 35 & 100,00 \\
\hline & \multirow{5}{*}{ Re-use } & Normal-Hipertensi & 23 & 65,70 \\
\hline & & Ringan & & \\
\hline & & Hipertensi & 13 & 34,30 \\
\hline & & Hipertensi Berat & & \\
\hline & & Total & 35 & 100,00 \\
\hline \multirow{6}{*}{ Adekuasi } & \multirow{3}{*}{ Single-use } & Adekuat & 16 & 45,70 \\
\hline & & Tidak Adekuat & 19 & 54,30 \\
\hline & & Total & 35 & 100,00 \\
\hline & \multirow{3}{*}{ Re-use } & Adekuat & 14 & 40,00 \\
\hline & & Tidak Adekuat & 21 & 60,00 \\
\hline & & Total & 35 & 100,00 \\
\hline
\end{tabular}

\section{(1) Tekanan Darah}

Tekanan darah kategori normal sampai hipertensi ringan memiliki jumlah terbanyak yaitu sebanyak 23 orang $(65,70 \%)$, diikuti dengan kategori hipertensi sedang sampai berat sebanyak 12 orang $(34,30 \%)$. Salah satu komplikasi yang sering terjadi pada penderita gagal ginjal adalah peningkatan tekanan darah (hipertensi). Hal ini dapat dipicu oleh peningkatan kinerja dari hormon renin, angiotensin dan aldosteron sebagai akibat dari 
penurunan laju filtrasi glomerulus (Daniel, 2006).

\section{(2) Adekuasi}

Responden yang mencapai adekuasi dikelompok single-use adalah sebanyak 16 orang $(45,70 \%)$ dan yang tidak mencapai adekuasi adalah sebanyak 19 orang $(54,30 \%)$. Sedangkan dikelompok re-use yang mencapai adekuasi HD adalah sebanyak 14 orang (40\%) dan yang tidak mencapai adekuasi adalah 21 orang (60\%). Adekuasi akan berpengaruh terhadap kualitas hidup karena berhubungan dengan kemampuan dialiser dalam mengeluarkan sisa hasil metabolisme berupa ureum, kreatinin, kalium dan natrium. Adekuasi HD sangat dipengaruhi oleh Qb (Quick blood) 200-300 cc/menit, durasi HD 10 sampai 12 jam dalam seminggu dengan frekuensi pemberian selama 2 sampai 3 kali dalam satu minggu (4-5 jam/HD) dan tingkat kerusakan membran (Black \& Hawks, 2010).

\section{d. Lama menjalani HD, Kadar Albumin, dan Kadar HB}

Tabel 4. Distribusi Kelompok Responden HD Single-use dan Re-use Berdasarkan Faktor Lama menjalani HD, Kadar Albumin, dan Kadar HB, di RSPAD Gatot Subroto dan RS PGI Cikini Jakarta, Periode April Sampai Dengan Juni, 2017 n (70)

\begin{tabular}{|c|c|c|c|c|c|}
\hline Var. & Kel. & Median & \pm SD & $\begin{array}{l}\text { Min- } \\
\text { Max }\end{array}$ & $95 \%$ CI \\
\hline \multirow{2}{*}{$\begin{array}{l}\text { Lama HD } \\
\text { (Bulan) }\end{array}$} & $\begin{array}{c}\text { Single- } \\
\text { use }\end{array}$ & 12,00 & $\pm 13,07$ & $8-48$ & $\begin{array}{l}13,94- \\
22,92\end{array}$ \\
\hline & Re-use & 12,00 & $\pm 14,41$ & $8-54$ & $\begin{array}{l}13,70- \\
23,61\end{array}$ \\
\hline \multirow{2}{*}{$\begin{array}{l}\text { Kadar } \\
\text { Albumin } \\
\text { (gr/dl) }\end{array}$} & $\begin{array}{c}\text { Single- } \\
\text { use }\end{array}$ & 3,20 & $\pm 0,40$ & $2,7-4,5$ & $3,09-3,37$ \\
\hline & Re-use & 3,163 & $\pm 0,48$ & $2,2-4,5$ & $2,99-3,33$ \\
\hline \multirow{2}{*}{ Kadar Hb } & Single- & 9,38 & $\pm 1,06$ & $7,0-12$ & $9,02-9,70$ \\
\hline & Re-use & 9,69 & $\pm 1,08$ & $7,0-11,7$ & $\begin{array}{c}9,32- \\
10,069\end{array}$ \\
\hline
\end{tabular}

\section{(1) LamaMenjalani HD}

Variabel lama menjalani HD pada kedua kelompok baik single-use maupun re-use memiliki median (nilai tengah) sebesar 12 bulan. Pada kelompok single-use, lama menjalani HD paling singkat adalah selama 8 bulan dan terlama adalah selama 48 bulan. Sedangkan dikelompok re-use paling singkat menjalani HD adalah selama 8 bulan dan terlama adalah selama 54 bulan.

Rata-rata kadar $\mathrm{Hb}$ pada kelompok single-use adalah sebesar 9,38 gr/dl, sedangkan pada kelompok re-use adalah sebesar 9,69 gr/dl. Kadar $\mathrm{Hb}$ pada kedua kelompok tersebut termasuk rendah, karena $<10 \mathrm{gr} / \mathrm{dl}$. Hal ini dapat dipicu oleh karena penurunan kadar hormon eritropoetin akibat kerusakan sel-sel ginjal.

\section{(2) Kadar Albumin}

Kadar albumin pada responden yang menjalani HD single-use memiliki nilai tengah 3,20 gr/dl. Sedangkan pada responden HD re-use memiliki rata-rata adalah 3,16 gr/dl. Melihat nilai tengah dan rata-rata pada kedua kelompok dapat diketahui bahwa keduanya memiliki kadar albumin yang sama-sama rendah karena kurang dari < 3,50 gr/dl. Albumin merupakan protein utama dalam plasma dan menyusun sekitar $60 \%$ dari total protein plasma. Normal nilai albumin adalah 3,5-5 gr/dl, hasil penelitian tersebut menunjukkan bahwa kadar albumin pada responden baik yang menjalani HD metoda single-use dan re-use termasuk rendah (Hipoalbuminemia).

Hipoalbuminemia adalah salah satu komplikasi yang umum ditemui pada penyakit gagal ginjal 
yang menjalani HD. Hal ini dipicu oleh adanya kerusakan pada glomerulus ginjal dan membran dialiser pada saat dilakukannya HD (Henry \& Santisteban, 2013). Berdasarkan hasil telaah literarur dan hasil penelitian sebelumnya, pada pemakaian dialiser single-use dan re-use juga tidak akan berdampak pada kadar albumin responden. Proses sterilisasi yang dilakukan dengan baik dan benar akan menghindarkan kerusakan pada membran dan dapat pula meminimalkan residu zat sterilan pada dialiser yang akan berdampak pada kerusakan sel darah merah pada saat HD dilakukan (Nicola, 2012). Perubahan kadar albumin ini dapat pula disebabkan oleh beberapa hal diantaranya adalah penurunan sintesis albumin oleh karena pembatasan jumlah asupan protein dan penurunan intake karena nafsu makan yang menurun, kerusakan pada lambung oleh karena adanya gastritis uremik (Stone, 2010; Wein \& Kavoussi, 2012; Stolic, Trajkovic, Peric \& Subaric, 2010). Gastritis uremik dan gangguan saluran cerna pada umumnya akan menyebabkan penurunan pada kemampuan sistem digestif dalam melakukan metabolisme dan absorbsi terhadap makanan yang masuk kedalam sistem tersebut. Selain itu pula akan terjadi penurunan nafsu makan yang akan berdampak pada kurangnya intake makanan yang merupakan sumber nutrisi bagi pasien gagal ginjal (Nicola, 2010).

\section{(3) Kadar Hb}

Rata-rata kadar $\mathrm{Hb}$ responden yang menjalani HD single-use adalah 9,38 gr/dl, sedangkan pada $\mathrm{HD}$ re-use, rata-rata kadar $\mathrm{Hb}$ responden adalah 9,69 gr/dl. Dari data tersebut dapat pula diketahui bahwa kadar HB pada kedua kelompok rata-rata adalah rendah karena kurang dari $10 \mathrm{gr} / \mathrm{dl}$. Hasil ini menunjukkan bahwa rata-rata responden mengalami anemia, karena konsentrasi $\mathrm{Hb} \leq 10$ gr/dl. Pada penelitian ini terdapat lebih dari 20 responden (62\%) mengalami anemia.

Pada pasien gagal ginjal sering mengalami anemia dikarenakan oleh beberapa penyebab diantaranya kekurangan hormon eritropoeitin, hilangnya sel darah merah saat HD, dan kurang asupan nutrisi. Kekurangan hormon eritropoetin sangat umum terjadi pada laju filtrasi glomerulus kurang atau sama dengan $60 \mathrm{ml} / \mathrm{menit} / 1,73 \mathrm{~m}^{2}$, karena pada kondisi ini sintesis dari eritropoetin relatif menurun akibat kerusakan pada ginjal (Fearon \& Lazarus, 2012).

Berdasarkan hasil telaah literarur dan hasil penelitian sebelumnya, pada pemakaian dialiser single-use dan re-use tidak akan berdampak pada $\mathrm{Hb}$ responden. Proses sterilisasi yang dilakukan dengan baik dan benar akan menghindarkan kerusakan pada membran dan dapat pula meminimalkan residu zat sterilan pada dialiser yang akan berdampak pada kerusakan sel darah merah pada saat hemodialisis dilakukan (Nicola, 2010). Penelitian sebelumnya pernah meneliti ada atau tidaknya pengaruh penggunaan dialiser singleuse dan re-use terhadap kadar eritropoetin pada pasien gagal ginjal di unit hemodialisa RS Michigan AS, Hasilnya tidak ada pengaruh penggunaan metoda HD single-use dan re-use pada pasien gagal ginjal dengan nilai P: 0,35 (Fried \& Howman, 2013).

\section{e. Kualitas Hidup}

Tabel 5. Distribusi Kelompok Responden HD Single-use \& Re-use Berdasarkan Kualitas Hidup di RSPAD Gatot Subrot \& RS PGI Cikini Jakarta, Periode Agustus-November, 2017 ( $\mathrm{n}=70)$

\begin{tabular}{lllll}
\hline Var. & Kel. & Kategori. & $\mathbf{( n )}$ & $\mathbf{( \% )}$ \\
\hline \multirow{4}{*}{ Kualitas Hidup } & \multirow{2}{*}{ Single-use } & Baik & 16 & 45,70 \\
& & Buruk & 19 & 54,30 \\
\cline { 2 - 5 } & \multirow{2}{*}{ Re-use } & Total & $\mathbf{3 5}$ & $\mathbf{1 0 0 , 0 0}$ \\
& & Baik & 12 & 34,30 \\
& Buruk & 23 & 65,70 \\
& Total & $\mathbf{3 5}$ & $\mathbf{1 0 0 , 0 0}$ \\
\hline
\end{tabular}


Pada kelompok single-use maupun re-use sebagian besar memiliki kualitas hidup yang rendah, yaitu 19 orang $(54,30 \%)$ pada kelompok single-use dan sebanyak 23 orang $(65,75 \%)$ pada kelompok reuse. Hal ini dapat dipicu oleh karena ketercapaian adekuasi pada kedua kelompok responden masih rendah, sehingga akan berdampak terhadap kualitas hidup karena pengeluaran sisa-sisa hasil metabolisme tidak dapat maksimal seperti ureum dan kreatinin sehingga menyebabkan sindroma uremia (IRR, 2012).

\section{KESIMPULAN DAN SARAN}

Berdasarkan analisa hasil penelitian yang dilakukan, maka diperoleh kesimpulan sebagai berikut:

a. Karakteristik pasien gagal ginjal yang menjalani HD single-use maupun re-use: Ratarata umur responden pada kedua kelompok adalah diatas 40 tahun, umur paling muda adalah 25 tahun dan paling tua adalah 71 tahun. Jenis kelamin terbanyak adalah laki-laki yaitu sebanyak 27 orang $(77,10 \%)$ pada responden single-use dan sebanyak 22 orang $(62,90 \%)$ pada responden re-use. Pada responden singleuse, pekerjaan sebagai swasta memiliki jumlah terbanyak yaitu sebanyak $(34,30 \%)$, sedangkan pada responden re-use pekerjaan sebagai PNS dan wiraswasta memiliki jumlah terbanyak yaitu sebanyak $28,60 \%$.

b. Kadar HB pada kedua kelompok responden rata-rata kurang dari 9,69 gr/dl. Kadar $\mathrm{Hb}$ paling rendah adalah sebesar 7,0 gr/dl dan kadar $\mathrm{Hb}$ paling tinggi adalah sebesar 11,7 gr/dl. Responden memiliki kecenderungan untuk memiliki tekanan darah yang tidak normal (hipertensi). Terdapat 45,70\% responden dengan metoda single-use yang memiliki kualitas hidup yang baik dan 34,30\% responden dengan metoda re-use yang memiliki kualitas hidup yang baik. Kadar albumin pada responden HD single-use memiliki nilai tengah 3,20 gr/dl, Sedangkan responden HD re-use memiliki rata-rata adalah 3,16 gr/dl. Kadar albumin pada responden HD single-use memiliki nilai tengah $3,20 \mathrm{gr} / \mathrm{dl}$, sedangkan pada responden HD re-use memiliki rata-rata adalah 3,16 gr/dl. Rata-rata kadar $\mathrm{Hb}$ responden yang menjalani HD single-use adalah 9,38 gr/dl, sedangkan pada HD re-use, rata-rata kadar $\mathrm{Hb}$ responden adalah 9,69 gr/dl.

Perlu dilakukan penilaian kualitas hidup pada pasien gagal ginjal yang menjalani HD menggunakan alat ukur KDQOL pada setiap bulannya, sebagai bahan pertimbangan dalam memberikan asuhan keperawatan terhadap pasien tersebut.

\section{REFERENSI}

1. Black \& Hawks (2010). Medical \& Surgical Nursing Clinical Management for Positive Outcomes. 8th Edition. St Louis Missouri: Elsevier Saunders.

2. Carod \& Artal (2012). Determining quality of life in stroke survivors. Expert Review of Pharmacoeconomics \& Outcomes Research, 12(2), 199-211. Doi: 10.1586/erp.11.104

3. Daniel (2006). Age, Socioeconomic Status, and Exercise Self-Efficacy. The Gerontologist, 36(2), 157-164. Doi: 10.1093/geront/36.2.157

4. Dickson, Buck, \& Riegel. (2013). Multiple Comorbid Conditions Challenge Heart Failure Self Care by Decreasing Self Efficacy. Nursing Research, 62(1), 46.

doi:10.1097/NNR.0b013e31827337b3.Fu 1

5. Kessler \& Janet (2013). Psycolological aspects of Stroke rehabilitation. In: Stroke Rehabilitation: A function based approach. Gillen G. (Ed). St.Louis: Saunders Elsevier.

6. Maksum, M. (2015). The Relations Between Hemodialysis Adequacy, 4, 3943. Nephrology Nursing Journal. 82(2), 153-154, 156-158. USA: American Nephrology Association. http://doi.org/33-5557/s00115-7698-565.

7. Malekmakan, L., Haghpanah, S., Pakfetrat, M., Malekmakan, A., Alimanesh, M., Haghpanah, A. \& Khajehdehi, P. (2010). Dialysis adequacy and kidney disease outcomes quality initiative goals achievement in an iranian hemodialysis population. Iranian Journal of Kidney Diseases, 4(1), 39-43. 
8. Nicola (2012). Renal Nursing 4 th edition. USA: Balilere Tindal press.

9. Schunk \& Zimmerman (2012). Motivation and Self-Regulated Learning: Theory, Research, and Applications. Taylor 7 Francis Pub: New York Ave

10. Siegert \& Levack (2014). Rehabilitation Goal Setting: Theory, practice and evidence. Florida: Taylor \& Francis Group

11. Wein \& Kavoussi (2010). Nefrology Nursing; Clinical Aplication. International Edition. 9 th Edition. USA: Elsevier Saunders

12. Wein, Kavoussi, Novick, Partin \& Peters (2012). Campbell-walsh Urology. International Edition. Cambridge press: USA

13. IRR (2011). 4 th Report of Indonesian Renal Registry. Retrieved from http://www.pernefriinasn.org/Laporan/4th Annual Report Of IRR 2011.pdf

14. -------(2012). 5 th Report of Indonesian Renal Registry. Retrieved from http://www.pernefriinasn.org/Laporan/4th Annual Report Of IRR 2012.pdf
15. PERNEFRI (2012) Naskah Lengkap Simposium Nasional Peningkata Pelayanan Penyakit Ginjal Kronik dan Indonesia Renal Registry. Yogyakarta: Pernefri.

16. Polit \& Beck (2013). Nursing Research Generating and Assesing Evidence for Nursing Practice. 9 th Edition. Philadelpia: Lippincontt William \& Walkins

17. Price \& Willson (2010). Patofisiologi Konsep Klinis proses-proses penyalit edisi 7. Jakarta: EGC

18. Fearon \& Lazarus (2012). Biocompatibility of Dialysis Membranes: Effects of Chronic Complement Activation. USA: Kidney Int.

19. Roitt (2012). Introduction to The Immune System. In : Roitt I, Brostoff J, Male D, editors. Immunology. 2nd ed. St. Louis: Mosby

20. Rubin (2013). Uremia and Host Defenses Kidney Disease. UK: Sandrew Press.

21. Wish, Jay, Weigel \& Kelly (2014). Management of anemia in chronic kidney disease (predialysis) patients. International Kidney Seminar http//cjasn.asseminars.org/ 